\title{
Chapter 4 \\ The Path to Reform of ISDS: What Role for National Courts?
}

\subsection{Introduction}

Chapter 3 has reviewed the areas of interaction between investment arbitration tribunals and national courts in the current framework. This Chap. 4 examines how the role of national courts may change under each of the main scenarios for reform of the investor-State dispute settlement system that States are presently considering. The design options and legal challenges associated with these reform proposals have been analyzed elsewhere, ${ }^{1}$ as has the potential of each of them to address the alleged concerns with the existing system. ${ }^{2}$ With a view to taking that analysis further, this chapter seeks to outline what (if any) role domestic courts may play within each of the reform proposals.

To that end, we will consider four reform scenarios which envisage maintaining or establishing a mechanism for the resolution of disputes concerning an investment on the international plane, namely:

a. Improvement of the current investor-State arbitration system ("investment arbitration improved") (infra at Sect. 4.2);

b. Addition of an AM to the current investment arbitration regime (infra at Sect. $4.3)$;

c. Introduction of a MIC (with or without a built-in appeal) (infra at Sect. 4.4); and

d. Replacement of the current system with SSDS (infra at Sect. 4.5).

\footnotetext{
${ }^{1}$ See Gabrielle Kaufmann-Kohler and Michele Potestà (2016), First CIDS Report; Gabrielle Kaufmann-Kohler and Michele Potestà (2017), CIDS Supplemental Report.

${ }^{2}$ See the "concept papers" prepared by members of the Academic Forum on ISDS on "Matching Concerns and Reform Options", available at https://www.cids.ch/academic-forum-concept-papers. 
The options just mentioned are the main ones advanced in the discussions around reform of the investor-State dispute settlement system $^{3}$ and reflect the principal alternatives available for the design of dispute settlement systems. They also represent the broad spectrum of positions and views expressed in recent State practice and in the debate surrounding investment arbitration.

177. Reforming investor-State dispute settlement with an eye to considering the appropriate role that domestic courts may or should play within these different reform scenarios requires examining primarily the models of jurisdictional coordination between national and international fora and the role of national courts in support and control of these international fora (if any). The current framework of interaction between national and international tribunals, discussed supra at Sects. 3.2 and 3.3, may thus serve as a useful starting point to delineate relations between national and international tribunals for the reform efforts. In the following analysis, however, it will be seen that many of the existing rules examined earlier in this study would require adaptation to the new institutional settings envisaged by some of the reform options. ${ }^{4}$ Beyond those already examined, two other "jurisdiction-regulating" models (to use Yuval Shany's terminology) ${ }^{5}$ and their potential applicability to the investment framework will be reviewed, i.e. (i) preliminary rulings from domestic courts to international tribunals; and (ii) complementarity between domestic and international courts (infra at Sect. 4.6).

178. In addition to the four reform options enumerated in para. 176 above which entail an international remedy (whether investor-State or State-to-State), a fifth possible reform outcome is sometimes advocated by certain stakeholders, i.e. the replacement of the current system with domestic courts only, for all or some categories of disputes concerning investments. This fifth reform scenario will also be considered (infra at Sect. 4.7).

179. Before delving into each of these reform options, two observations are in order. First, in terms of system design, not only can international mechanisms be combined with national courts in various ways (which is the subject of this chapter), international mechanisms may also be combined with other international mechanisms. For instance, States could design dispute settlement mechanisms in which investment arbitration is combined with SSDS for certain questions of interpretation of the IIA. ${ }^{6}$ This latter type of combination is not systematically examined as it falls outside the scope of this study. Second, the five reform scenarios that have been chosen for discussion in this chapter are limited to dispute settlement mechanisms that lead to a binding decision. This means that this study does not examine methods such as

\footnotetext{
${ }^{3}$ See UNCITRAL Working Group III, Possible reform of investor-State dispute settlement (ISDS) Note by the Secretariat, A/CN.9/WG.III/WP.166. See also generally Roberts (2018), pp. 410-432. ${ }^{4}$ The following sections, by contrast, do not address State conduct for liability of domestic courts (discussed supra in chapter 3.4) which is a substantive question and thus outside the scope of the current reform discussions which are focused exclusively on dispute settlement and procedure.

${ }^{5}$ See generally Shany (2007), pp. 27-77.

${ }^{6}$ See Potestà (2015), pp. 249-273.
} 
mediation, conciliation, ombudsman, etc. This limitation in no way implies any judgment on the usefulness of these alternative mechanisms, which may well deserve to be the subject of a further study. It should also be noted that in any event non-binding methods of dispute resolution are usually combined with one of the binding options discussed here.

Finally, in terms of instruments for effecting the changes that are discussed in the following sections, depending on the reform option chosen these may involve (i) the amendment of IIAs; (ii) the negotiation of an opt-in Mauritius Convention-type plurilateral treaty able to effect changes en bloc for a number of treaties; and/or (iii) the negotiation of statutes or constitutive treaties for the establishment of new international bodies (the AM Statute or MIC Statute). ${ }^{7}$

\subsection{Investment Arbitration "Improved"}

One option that is currently being considered is the reform of investment arbitration through "incremental" changes or improvements, i.e. reform short of creating new standing bodies. "Improving" investment arbitration in this manner may for instance include effecting changes in respect of the appointment of and rules of conduct for arbitrators. This may include providing for appointment predominantly by arbitral institutions or effected jointly by disputing parties, creating a roster-system, adopting ethical rules, reinforcing procedures for the dismissal of frivolous claims, enhancing transparency of proceedings and the like. These more "limited" changes will in and of themselves not affect the relationship between the "improved" investor-State arbitral mechanism and the domestic courts. Thus, the various modes of interaction between national courts and international tribunals described supra in Chap. 3 would continue to apply.

The panoply of solutions on the coordination between investment tribunals and domestic courts described previously can, however, guide States wishing to recalibrate the coordination of investment arbitration and domestic courts in a different way from what they have done so far, in line with their policy preferences. ${ }^{8}$ States may for instance introduce, remove, or re-modulate exhaustion of local remedies requirements, domestic litigation requirements, fork-in-the-road clauses or waiver clauses in their existing and future IIAs. As mentioned previously, certain more recent treaties already formulate fork-in-the-road and waiver clauses with a

\footnotetext{
${ }^{7}$ See generally on these questions, Gabrielle Kaufmann-Kohler and Michele Potestà (2016), First CIDS Report, Section VII.

${ }^{8}$ For suggestions on the more meaningful role that exhaustion of local remedies could play, see for instance the following submissions made by States in the UNCITRAL WGIII discussions: A/CN.9/ WG.III/WP.156, Submission from the Government of Indonesia, para. 17; A/CN.9/WG.III/ WP.161, Submission from the Government of Morocco, Annex I, paras. 9 and 14; A/CN.9/WG. III/WP.176, Submission from the Government of South Africa, paras. 43-46.
}

181. 
view to remedying certain shortcomings arising from what have been viewed as excessively formalistic applications of the so-called triple identity test. ${ }^{9}$

\subsection{Investment Arbitration + Appeal}

183. This reform option envisages the creation of an AM for awards rendered in investorState arbitration proceedings. ${ }^{10}$ The creation of an appeal layer does not in and of itself have an effect on the relationship between the first-instance arbitral jurisdiction and domestic courts, which absent specific rules would continue to be governed by the framework provided under the specific IIA. Thus, for instance, if an IIA provides for an 18-month domestic litigation requirement as a pre-condition to accessing the arbitral tribunal, the addition of an appeal will in and of itself not affect such requirement which will continue to exist as far as the first level of jurisdiction is concerned.

184. Nevertheless, the introduction of an AM may significantly affect the role of domestic courts in controlling the arbitration, especially at the annulment and enforcement stages. These aspects will need to be carefully examined if and when an appellate mechanism for investor-State arbitral awards is established. The legal issues to be considered in this context are significant and require taking into account the distinctions between ICSID and non-ICSID arbitrations, which are subject to different legal regimes. ${ }^{11}$ This holds especially true if States were to establish one, single, stand-alone AM with appellate jurisdiction over both ICSID and non-ICSID awards. ${ }^{12}$ The following discussion assumes (i) the creation of such a stand-alone AM (as opposed to multiple treaty-specific AMs), and (ii), as far as ICSID awards are concerned, the permissibility of an inter se modification of the ICSID Convention pursuant to Article 41 of the VCLT, on which these authors have taken an affirmative view. ${ }^{13}$

185. In designing an AM for investor-State arbitral awards, one threshold question requiring consideration is whether the new AM should be subject to a national lex

\footnotetext{
${ }^{9}$ See supra para. 83.

${ }^{10}$ See generally Gabrielle Kaufmann-Kohler and Michele Potestà (2016), First CIDS Report, section VI.

${ }^{11}$ See supra paras. $118-119$.

${ }^{12}$ The ICSID Secretariat 2004 paper, for instance, suggested that the creation of an ICSID Appeals Facility could apply to ICSID and non-ICSID awards. See ICSID Secretariat, Discussion Paper 2004, Annex, para. 1 (suggesting that the ICSID Appeals Facility "would best be designed for use in conjunction with both forms of ICSID arbitration, UNCITRAL Rules arbitration and any other form of arbitration provided for in the investor-to-State dispute-settlement provisions of investment treaties").

${ }^{13}$ See Gabrielle Kaufmann-Kohler and Michele Potestà (2016), First CIDS Report, Section VII.B.2. See also McGarry and Ostřanský (2017), pp. 1001-1013. For a different view, see Jansen Calamita (2017), pp. 585-627.
} 
arbitri (like non-ICSID investment arbitrations) or be de-localized and governed only by international law (like ICSID arbitrations). ${ }^{14}$ One possibility would be that the procedural law applicable to the AM proceedings would be the same as the procedural law governing the first-instance proceedings. Thus, to give an example, proceedings in an UNCITRAL investment arbitration seated in Switzerland would be subject to Chapter 12 of the PILA for both the first instance and appeal proceedings ${ }^{15}$; whereas in an ICSID arbitration subject to appeal, both the first instance and appeal proceedings would be governed by international law. This "dual track" would entail two types of legal regimes applicable to appeal proceedings, including for awards rendered under the same IIA, if the IIA provides for a choice between ICSID and non-ICSID arbitration. A different possibility to be explored would be to have a completely de-localized AM procedure subject only to international law for all types of appeal awards. The legal consequences of these choices are important because, as seen above in Sect. 3.3, national courts potentially play a different role in an arbitration governed by a national lex arbitri as opposed to an "a-national" arbitration.

The treaty establishing the AM (the AM Statute) should thus regulate these matters to avoid uncertainties, in particular as far as annulment and enforcement are concerned, which are the two areas in which court intervention will be most relevant.

Starting with the relationship between a potential AM and annulment, these authors have taken the view that the prospective AM should substitute rather than be combined with any annulment-type review present under national law or the ICSID Convention. ${ }^{16}$ In other words, appeal and annulment remedies appear mutually exclusive. This is in part because grounds for appeal are normally broader than (and thus already include) the usual grounds for annulment. ${ }^{17}$ Furthermore, providing for the possibility of annulment of appeal awards would de facto create a threetier dispute settlement system, which would go against the objective of efficiency in terms of time and costs. ${ }^{18}$

With this assumption in mind (i.e. that no annulment remedies will be provided for appeal awards), for non-ICSID arbitrations, the AM Statute should exclude any role of domestic courts for the purposes of annulment of appeal awards, i.e. the AM Statute should provide for a waiver of judicial review in respect of awards rendered by the AM, in order to avoid a duplication of remedies. ${ }^{19}$ Because not all domestic laws would necessarily recognize such a waiver as a valid agreement to exclude the

\footnotetext{
${ }^{14}$ See Gabrielle Kaufmann-Kohler and Michele Potestà (2016), First CIDS Report, paras. 193-195.

${ }^{15}$ For this solution in the field of commercial arbitration see, e.g., AAA Optional Appellate Arbitration Rules, Rule A-14 ("Unless all parties and the appeal tribunal agree otherwise, the appeal shall be conducted at the same place of arbitration as the underlying arbitration").

${ }^{16}$ See Gabrielle Kaufmann-Kohler and Michele Potestà (2016), First CIDS Report, paras. 115, 196.

${ }^{17} \mathrm{Ibid}$.

${ }^{18} \mathrm{Ibid}$. On this point, see also the discussion in van den Berg (2019), pp. 104-107.

${ }^{19}$ See Gabrielle Kaufmann-Kohler and Michele Potestà (2016), First CIDS Report, para. 197.
} 
right to seek annulment before their courts, Contracting Parties should consider passing legislation to this effect. In that context, it should also be provided that the arbitration (including the appeals phase, should it not be de-localized for all types of proceedings) must be seated in a State that is a party to the AM Statute. Otherwise, in circumstances where the seat is situated in a third State, there is a risk that such State would not recognize the waiver of judicial review as valid. With regard to ICSID awards, the AM Statute should similarly exclude any annulment of ICSID awards under Article 52 of the ICSID Convention.

189. With regard to enforcement, the question arises as to the effects of adding an AM layer on the enforcement of an award which has been subject to appeal under the AM. ${ }^{20}$ As a preliminary remark, it is important to note that, as is the case with annulment, any specific enforcement regime set out in the AM Statute will only bind the Contracting Parties to the Statute. ${ }^{21}$

190. With regard to enforcement in their territories, Contracting Parties may opt for one single enforcement regime for all appeal awards (whether rendered in non-ICSID or ICSID arbitrations). Alternatively, they could put in place distinct enforcement regimes depending on whether the first-instance award is an ICSID or a non-ICSID award. The former could for instance be enforced pursuant to an Article 54-type rule, whereas the latter would be subject to the NYC regime. It should be noted that if States opt for a dual enforcement regime, depending on the nature of the underlying arbitration, there could potentially be two different enforcement regimes applicable to appeal awards rendered under the same IIA, where the IIA provides for an option between ICSID and non-ICSID arbitrations. This, in practice, would mean that the scope of review of domestic courts at enforcement would be broader for certain awards (Article V of the NYC) than for others (ICSID Convention Article 54-type provision).

191. With regard to enforcement in third States, an award subject to an appeal or the appeal award itself ${ }^{22}$ would be enforceable under the $\mathrm{NYC},{ }^{23}$ because the addition of an appellate layer does not change the nature of the arbitration process. ${ }^{24}$ This is true, of course, for a non-ICSID award that is subject to appeal. With regard to ICSID

\footnotetext{
${ }^{20}$ On enforcement of appeal awards see Gabrielle Kaufmann-Kohler and Michele Potestà (2016), First CIDS Report, Section V.E; van den Berg (2019), pp. 85-104.

${ }^{21}$ VCLT, Article 34.

${ }^{22}$ Under the NYC, the first-instance award can be refused recognition and enforcement if it is being appealed or is still open to appeal, under Article V, para. 1(e) ("award that has not yet become binding"). For the position in Switzerland, see Kaufmann-Kohler and Rigozzi (2015), p. 528. As noted by van den Berg, "[t]he IIA can set forth whether a first instance award can be enforced pending arbitral appeal or the period of time for lodging the appeal. If no such provisions are contained in the IIA (or rules of procedure issued thereunder), the fallback interpretation can be relied upon, i.e. the award becomes binding at the moment when it is no longer open to an appeal." (see van den Berg 2019, para. 141).

${ }^{23}$ Gabrielle Kaufmann-Kohler and Michele Potestà (2016), First CIDS Report, para. 199.

${ }^{24}$ Gabrielle Kaufmann-Kohler and Michele Potestà (2016), First CIDS Report, Sections VI.E and V.E.2.c.
} 
awards subject to an appeal, non-parties to the inter se modification would not be bound by the special enforcement regime that were to be established along the lines of Article 54 of the ICSID Convention. Rather, they would be in a situation similar to that of non-ICSID Contracting Parties in respect of an ICSID award. In other words, they would have to enforce the ICSID award in accordance with the NYC. ${ }^{25}$ This matter can also be viewed from a different angle. Suppose the AM Statute were to provide a waiver of the grounds for refusal of enforcement (which provision would bind both the State Contracting Parties and the investor which accepts to arbitrate under the treaty). What effect would such a waiver have on third States? It would seem that it would be for each (third) State to determine to what extent a waiver of the grounds for refusal of enforcement included in the AM Statute would be valid in their own legal system. That being so, it is doubtful that the waiver would be effective. Even if specific language is used, as is required under some legislation, it would remain that "the grounds for refusal of enforcement in paragraph 2 of Article V of the New York Convention are legally not capable of being waived or contracted out of". 26

In sum, with regard to the role of domestic courts in a reform scenario providing an AM for investor-State arbitral awards, the domestic courts' role at annulment is susceptible to being significantly curtailed when compared with their role under the existing regime vis-à-vis non-ICSID arbitrations. This is a natural consequence of the addition of a second layer of review which makes the courts' supervisory role largely unnecessary. In enforcement matters, domestic courts are likely to keep a role in third countries not parties to the AM Statute, as well as in Contracting Parties depending on the enforcement regime set out in the Statute.

\subsection{Multilateral Investment Court}

If a MIC is created, how is the role of domestic court going to change? ${ }^{27}$ Once again, based on the categories of jurisdictional coordination reviewed in chapter 3.2 above, States may envisage designing a role for domestic courts in the sequential or alternative modes previously examined. As an example of a regulation of the interplay between domestic courts and a standing investment court, one can look to the constitutive instrument of the Arab Investment Court, which provides for a fork-in-the-road clause. ${ }^{28}$

\footnotetext{
${ }^{25}$ See Gabrielle Kaufmann-Kohler and Michele Potestà (2016), First CIDS Report, paras. 200, 245.

${ }^{26}$ van den Berg (2019), para. 149.

${ }^{27}$ The following discussion assumes that the prospective MIC will be regulated by a new "MIC Statute" and "Rules of the Court", rather than by modified arbitration rules.

${ }^{28}$ See Unified Agreement for the Investment of Arab Capital in the Arab States (opened for signature 26 November 1980, entered into force 7 September 1981), Articles 31 and 32, available at https://investmentpolicy.unctad.org/international-investment-agreements/treaty-files/2394/down load ("The Arab investor may have recourse to the courts in the State where the investment is made
} 
194. In terms of treaty drafting and taking into account that consent to the jurisdiction of the MIC would be contained in a separate instrument (a future IIA or an existing one for which an opt-in has been exercised), ${ }^{29}$ there seem to be two possibilities.

195. First, the MIC Statute may simply defer to any jurisdictional requirements contained in the underlying IIA over which it has jurisdiction. Thus, for instance, where an IIA between States A and B provides for an 18-month litigation requirement, such requirement would continue to apply to proceedings to be brought before the MIC. By contrast, an IIA between States C and D without any such requirement would allow a qualifying investor to directly access the MIC without having to first resort to domestic courts. Under this approach, the MIC Statute would simply defer to any jurisdictional or admissibility requirement (including those aimed at regulating the interplay with domestic courts, including exhaustion, litigation, fork-in-theroad, or waiver clauses) contained in the underlying IIA.

196. An alternative approach would be to include within the MIC additional jurisdictional or admissibility requirements to be met in addition to those governing under the IIA. Thus, the MIC Statute could contemplate any of the sequential or alternative methods discussed above, for instance a fork-in-the-road clause, that would apply to any proceedings brought before the Court. There would be nothing unusual in this approach; it is adopted by the ICSID Convention, which provides for autonomous jurisdictional requirements (e.g., definition of "investor", nationality restrictions, etc.) which must be met in addition to the conditions set out in the relevant IIA. Further, if the MIC Statute wishes to provide greater flexibility to Contracting States (with a view to reaching a wider consensus), it could leave it to the Contracting States to opt into some but not all of these requirements (like Article 26 of the ICSID Convention for exhaustion of local remedies). For instance, the MIC Statute could provide that no exhaustion of local remedies is required before the Court, unless a Contracting State indicates otherwise when acceding or ratifying the treaty.

197. The role of courts in support and control of the proceedings may considerably change as a result of the transition from arbitration to a standing body, depending on how the MIC is conceived. If, as is likely, the MIC is a self-contained court, governed solely by public international law, ${ }^{30}$ the role of domestic courts would be much curtailed:

\footnotetext{
according to the rules of jurisdiction within such State in the case of matters which fall within the jurisdiction of the Court. However, where the Arab investor brings an action before one authority, he must refrain from so doing before the other"; "Where there is a conflict of jurisdiction between the Court and the courts of a State Party, the decision of the Court on the matter shall be final"). See also Hasaan (2019), p. 124 (discussing the 2013 Amendment to the Arab Investment Agreement, noting that such amendment contains a similar fork-in road clause, and discussing relevant cases before the Arab investment Court).

${ }^{29}$ Without prejudice to the possibility for consent to the MIC to be given also in an investment contract between a foreign investor and a State (or State-entity) and through an offer in national legislation. These are policy choices on the jurisdiction of the prospective MIC which are for States to make.

${ }^{30}$ See Gabrielle Kaufmann-Kohler and Michele Potestà (2016), First CIDS Report, Section V.5.
} 
- The standing nature of the Court would render any role for domestic courts in the appointment of adjudicators unnecessary.

- With regard to challenges to adjudicators, which are likely to be much less frequent than for arbitrators, the MIC Statute could confer the power to decide on disqualification to an external authority, for instance the PCA SecretaryGeneral, the ICSID Secretary-General, or the ICJ President, or reserve this function to an internal body of the Court. ${ }^{31}$

- In respect of the faculty to seek provisional remedies from domestic courts which may exist under national laws of procedure, the MIC Statute could provide for a solution akin to the one found in the ICSID Convention context, which excludes any such role (unless otherwise provided by the parties). ${ }^{32}$

- The MIC Statute is also likely to provide for its own system of review of firstinstance decisions either in the form of an annulment or of an appeal. ${ }^{33}$

- A residual role will remain for domestic courts at the enforcement stage, an issue which these authors analyzed in the First CIDS Report. ${ }^{34}$

\subsection{Replacing the Existing System with State-to-State Dispute Settlement}

An option that is sometimes discussed is to allow only the home State to enforce the IIA obligations on behalf of their investors through SSDS. ${ }^{35}$ This reform option would essentially entail a return to the pre-investment arbitration system of diplomatic protection and resemble the situation under the FCN treaties pre-dating modern BITs. The potential drawbacks of this option have been highlighted in Chap. $2 .^{36}$

What effect would a reform proposal aimed at strengthening SSDS have on the role of domestic courts? As previously seen, under customary international law, where the home State brings a claim for injury to one of its nationals against another

\footnotetext{
${ }^{31}$ Gabrielle Kaufmann-Kohler and Michele Potestà (2017), CIDS Supplemental Report, para. 104.

${ }^{32}$ See supra at chapter 3.3.3.

${ }^{33}$ See generally Gabrielle Kaufmann-Kohler and Michele Potestà (2016), First CIDS Report, section V.D.

${ }^{34}$ See Gabrielle Kaufmann-Kohler and Michele Potestà (2016), First CIDS Report, section V.E.

${ }^{35}$ See for recent practice in this respect Australia-Japan EPA (2014); Australia-Malaysia FTA (2012); Australia-New Zealand Investment Protocol (2011); Japan-Philippines EPA (2006); Australia-U.S. FTA (2004); Comprehensive Progressive Agreement for Trans-Pacific Partnership (2018) as between certain countries only (see the side instruments exchanged by New Zealand with a number of treaty parties, e.g. Australia and Peru, which exclude investor-State dispute settlement as between those parties, available at https://www.mfat.govt.nz/en/trade/free-trade-agreements/ free-trade-agreements-in-force/cptpp/comprehensive-and-progressive-agreement-for-trans-pacificpartnership-text-and-resources/).

${ }^{36}$ See supra at 2.2.2.2 and 2.3.
}

198. 
State (as opposed to a claim for direct injury to itself), the national must first have exhausted all local remedies. ${ }^{37}$ In Italy $v$. Cuba, one of the few inter-State cases under a BIT, ${ }^{38}$ the tribunal confirmed that the exhaustion rule was a prerequisite for Italy's diplomatic protection claim under the BIT. ${ }^{39}$

200. Thus, a reform option centered around the enhanced prominence of SSDS would entail a greater role for domestic courts. In their treaties, States could, however, waive exhaustion of local remedies as pre-condition to SSDS, or they could conceive of SSDS and domestic courts as alternative fora. The Brazilian model Cooperation and Investment Facilitation Agreements (CIFA), which does not provide for investor-State arbitration, but opts for a framework involving an Ombudsman, a Joint Committee of the Treaty Parties, and SSDS, specifies that if an investor has obtained a domestic court judgment with res judicata effect, resort to SSDS under the treaty is foreclosed; if the domestic court litigation is pending, the investor's waiver of domestic court proceedings is a pre-condition to the home State's commencement of SSDS proceedings. ${ }^{40}$

\footnotetext{
${ }^{37}$ See supra at 2.2.2.2.

${ }^{38}$ See Italian Republic v. Republic of Cuba, ad hoc arbitral tribunal, Interim Award, 15 March 2005; Potestà (2012), pp. 341-347. For the operation of the exhaustion rule in a different context, see Article 295 of the United Nations Conventions on the Law of the Sea (UNCLOS), providing that "[a]ny dispute between States Parties concerning the interpretation or application of this Convention may be submitted to the procedures provided for in this section only after local remedies have been exhausted where this is required by international law". On this see Marotti (2017), pp. 36-62. ${ }^{39}$ See Italian Republic v. Republic of Cuba, ad hoc arbitral tribunal, Interim Award, 15 March 2005, paras. 88-91.

${ }^{40}$ See Brazilian CFIA Model, Article 24, para. 13(b) (“This paragraph [possibility to resort to Stateto-State arbitration for the purposes of seeking the recovering of compensation for "damages caused by the measure in question under the obligations of this Agreement"] shall not be applied to a dispute concerning a particular investor which has been previously resolved and where protection of res judicata applies. If a[n] investor had submitted claims regarding the measure at issue in the Joint Committee to local courts or an arbitration tribunal of the Host State, the arbitration to examine damages can only be initiated after the withdrawal of such claims by the investor in local courts or an arbitration tribunal of the Host State. If after the establishment of the arbitration, the existence of claims in local courts or arbitral tribunals over the contested measure is made known to the arbitrators or the Parties, the arbitration will be suspended", emphasis added). The second part of the rule is akin to a waiver provision examined supra at 3.2.2.2. On the Brazilian CFIA Model, see generally Vidigal and Stevens (2018), pp. 475-512; Bernasconi-Osterwalder and Dietrich Brauch (2015), pp. 1-16. Article 24, para. 14(c) of the Brazil-Colombia CFIA (2015) provides that State-toState arbitral awards are to be treated as though they are judgments rendered by a local court for the purposes of enforcement (similar to what Article 54 ICSID Convention provides for ICSID awards).
} 


\subsection{Two Alternative Models: Preliminary Rulings and Complementarity}

Beyond the means of coordination to which IIAs typically resort (exhaustion of local remedies, domestic litigation requirements short of exhaustion, fork-in-the-road, and waiver clauses), it may be instructive to address two coordination modes, or "jurisdiction-regulating" norms, existing in other areas of public international law, namely preliminary rulings and complementarity. ${ }^{41}$ Could these be transposed to the investment treaty realm?

A preliminary ruling proceeding is a procedure by which a court refers a decision on a specific issue arising in pending proceedings to another court, normally seeking the interpretation of a legal norm from the other court. The proceedings before the court seeking the ruling are typically suspended pending the determination by the other court, which will usually bind the court requesting it. That court will then incorporate the content of the ruling into its overall resolution of the dispute.

The most well-known example is the preliminary ruling procedure pursuant to Article 267 of the Treaty on the Functioning of the European Union (ex Article 234 of the Treaty establishing the European Community), whereby a court of a Member State of the European Union may, and in certain instances must, request the CJEU to give a ruling on the interpretation of a question of EU law that arises in an action pending before the Member State court and is unsettled. ${ }^{42}$ In the context of the $\mathrm{EU}$, the preliminary ruling procedure was needed to foster the unity of the EU legal order in spite of the decentralized interpretation and application at the national level. It has worked as a powerful tool to ensure the uniform application of EU law and thereby the preservation of the legal unity of the Union. ${ }^{43}$

The transposition of a preliminary ruling mechanism to investment arbitration (i.e. could an investment tribunal seek a preliminary ruling on an unsettled issue of investment law from a permanent body) has been examined elsewhere. ${ }^{44}$ Here, in

\footnotetext{
${ }^{41}$ See generally Shany (2007), pp. 33-36.

${ }^{42}$ See Consolidated version of the Treaty on the Functioning of the European Union ("TFEU"), OJ C 326, 26 October 2012, Article 267. For preliminary ruling procedures in other international courts and tribunals, see Virzo (2011), pp. 285-313.

${ }^{43}$ In the words of the CJEU, "[the] obligation to refer imposed by the third paragraph of Article $234 \mathrm{EC}$ [now Article $267 \mathrm{TFEU}$ ] is based on cooperation, established with a view to ensuring the proper application and uniform interpretation of [EU] law in all the Member States, between national courts, in their capacity as courts responsible for the application of [EU] law, and the Court of Justice [...]". See Case C-495/03 Intermodal Transports BV v. Staatssecretaris van Financiën [2005] ECR I-8151, para. 38 (emphasis added). On preliminary rulings in EU law, see generally de la Mare and Donnelly (2011), pp. 363-406.

${ }^{44}$ See Gabrielle Kaufmann-Kohler and Michele Potestà (2016), First CIDS Report, Section V.D.4.a (discussing, in the context of a prospective MIC, the possible creation of a panel allowed to refer certain questions to either a separate body established for that purpose or to a special chamber of the MIC). See also generally Kaufmann-Kohler (2004), p. 221; Kaufmann-Kohler (2005), p. 8; Kaufmann-Kohler (2007), p. 378; Schreuer (2006), pp. 23; Schreuer (2008), pp. 207-212; DielGligor (2017).
} 
line with the aim of this study, the purpose is to inquire whether it could be contemplated that a national court seized of an issue of international investment law could seek a preliminary ruling from one of the four international dispute settlement systems envisaged above (investment arbitration, AM, MIC, SSDS). ${ }^{45}$ Or, put differently, assuming a dispute arising out of an IIA is brought before a national court, could that court refer an unsettled question of interpretation of that IIA to an international dispute settlement body? In accordance with the preliminary ruling logic, the international body from which the ruling is requested would not dispose of the dispute pending before the national forum. It would merely authoritatively determine a discrete issue of international investment law to assist the domestic court in resolving the dispute. At the same time, that practice would work toward the "uniformization" of international investment law.

205. While in theory conceivable, the transposition of this model in the investment law setting at issue appears difficult, if only because the governing law before the domestic court would not necessarily be international law. Indeed, as was seen above, in certain legal systems, domestic courts cannot apply IIAs directly as a result of constitutional limitations. ${ }^{46}$ Hence, in such a situation, a preliminary ruling mechanism would serve no purpose.

206. An alternative model for the interplay between domestic and international jurisdiction is the principle of complementarity enshrined in the Rome Statute of the International Criminal Court. ${ }^{47}$ Under this principle, States have the first responsibility and right to prosecute the most serious crimes of international concern. The International Criminal Court may only exercise jurisdiction where the national legal system "is unwilling or unable genuinely to carry out the investigation or prosecution" (Article 17 of the Rome Statute). ${ }^{48}$ Transposed to investment disputes, the international settlement mechanism would exercise a sort of "jurisdiction of last resort"; it would do so in the absence of a credible judicial alternative at the national

\footnotetext{
${ }^{45}$ See also Schill and Vidigal (2018), p. 19.

${ }^{46}$ See supra at 3.2.2.1. See also Freya Baetens (2015), Transatlantic Investment Treaty Protection A Response to Poulsen, Bonnitcha and Yackee, Paper No. 4 in the CEPS-CTR project "TTIP in the Balance" and CEPS Special Report No. 103 / March 2015, p. 4.

${ }^{47}$ See Rome Statute of the International Criminal Court ("Rome Statute"), 1 July 2002, 2187 UNTS 90, Preamble ("the International Criminal Court established under this Statute shall be complementary to national criminal jurisdiction"), Article 1 (The International Criminal Court "shall be a permanent institution and shall have the power to exercise its jurisdiction over persons for the most serious crimes of international concern, as referred to in this Statute, and shall be complementary to national criminal jurisdictions"), and Article 17 ("[...] the Court shall determine that a case is inadmissible where: (a) The case is being investigated or prosecuted by a State which has jurisdiction over it, unless the State is unwilling or unable genuinely to carry out the investigation or prosecution; (b) The case has been investigated by a State which has jurisdiction over it and the State has decided not to prosecute the person concerned, unless the decision resulted from the unwillingness or inability of the State genuinely to prosecute; (c) The person concerned has already been tried for conduct which is the subject of the complaint, and a trial by the Court is not permitted under article 20, paragraph $3 ;[\ldots] ")$.

${ }^{48}$ See generally Stigen (2008), El Zeidy (2008).
} 
level, i.e. when the domestic courts are "unwilling or unable" to adjudicate the dispute. Complementarity may be regarded as having the advantage of strengthening the capabilities of domestic courts while at the same time preserving international remedies for cases where justice cannot be rendered at the national level. This said, the International Criminal Court is built upon a complex interaction between the State Parties, the U.N. Security Council, the Prosecutor, and the other organs of the Court. These actors or their equivalents are largely absent in the adjudication of investment disputes. As a result, the implementation of a jurisdiction of last resort does not appear practically feasible and would at best be fraught with uncertainty.

In conclusion, while the preliminary rulings and the complementarity models make for an interesting coordination of domestic and international jurisdictions, their implant within the investment framework appears either inapposite (preliminary rulings) or not easily implementable (complementarity).

\subsection{Replacing the Existing System with Domestic Courts}

Finally, under the most "radical" reform option advanced by certain stakeholders, domestic courts should become the exclusive forum for the settlement of investment disputes. As discussed in previous parts of this study, a wholesale return to only domestic remedies should be considered with caution in particular for States where the courts' impartiality and the rule of law might be open to question.

States wishing to pursue this option would need to either (i) amend their IIAs to eliminate investor-State arbitration and SSDS clauses; or (ii) terminate their IIAs entirely. Under the first option, domestic courts may apply IIAs, if so allowed under their legal system. Under the second option, investment disputes would simply be adjudicated by reference to domestic legal standards.

Recent State practice provides some examples of the greater role domestic remedies could play in the adjudication of disputes between States and foreign investors.

South Africa, for instance, which has adopted a policy against investor-State dispute settlement, has "recently reviewed all of its IIAs and terminated most of them". 49 The investment protection regime is now established under domestic law, in particular, the Protection of Investment Act No. 22 of $2015 .{ }^{50}$ According to the Act, foreign investors are entitled to the same treatment as that afforded to South African investors in like circumstances, save for certain exceptions. ${ }^{51}$ The "domestication" of the investment regime not only applies to substantive protection,

\footnotetext{
${ }^{49}$ See Mbengue and Schacherer (2017), p. 442.

${ }^{50}$ South Africa, Protection of Investment Act 2015 (Act 22 of 2015), Government Gazette, 606, No. 39514, 15 December 2015, available at https://investmentpolicy.unctad.org/investment-laws/laws/ 157/investment-act.

${ }^{51}$ Article 9 of the South Africa, Protection of Investment Act 2015.
}

208.

209. 
it also extends to procedural remedies. The Act does not provide for investor-State arbitration, but only for recourse to domestic courts. ${ }^{52}$ The Government may, however, consent to inter-State arbitration with the investor's home State on a case-by-case basis, subject to the exhaustion of local remedies. ${ }^{53}$

212. Some States have followed a different approach, which has been referred to as "selective judicialisation". ${ }^{54}$ Under this approach, the treaty excludes from the jurisdiction of the international tribunal certain "sensitive areas" which are reserved for domestic courts. For instance, the 2015 Indian Model BIT excludes from the scope of the treaty any measure by a local government (as well as any law or measure regarding taxation), compulsory licenses granted in relation to intellectual property, government procurement, subsidies or grants and services supplied in the exercise of governmental authority. ${ }^{55}$ As a consequence, disputes arising out of measures of this nature cannot be resolved through the settlement mechanisms foreseen in the treaty and must be brought before national courts. ${ }^{56}$

\section{References}

Bernasconi-Osterwalder N, Dietrich Brauch M (2015) Comparative commentary to Brazil's cooperation and investment facilitation agreements (CIFAs) with Mozambique, Angola, Mexico and Malawi. International Institute for Sustainable Development, pp 1-16

de la Mare T, Donnelly C (2011) Preliminary rulings and EU legal integration: evolution and stasis. In: Craig P, de Búrca G (eds) The evolution of EU law, 2nd edn. Oxford University Press, pp 363-406

Diel-Gligor K (2017) Towards consistency in international investment jurisprudence. A preliminary ruling system for ICSID arbitration. Brill I Nijhoff

El Zeidy MM (2008) The principle of complementarity in international criminal law: origin, development and practice. Martinus Nijhoff

Hasaan AA (2019) The 2013 amendments to the Arab Investment Agreement. ICSID Rev Foreign Invest Law J 34:107-135. pp. 1-29

Jansen Calamita N (2017) The (in)compatibility of appellate mechanisms with existing instruments of the investment treaty regime. J World Invest Trade 18(4):585-627

\footnotetext{
${ }^{52}$ Article 13, para. 4 of the South Africa, Protection of Investment Act 2015.

${ }^{53}$ Article 13, para. 5 of the South Africa, Protection of Investment Act 2015.

${ }^{54}$ See Schill and Vidigal (2018), p. 4.

${ }^{55}$ India Model BIT (2015), Article 2, para. 2.4.

${ }^{56}$ For a similar approach, see Comprehensive Progressive Agreement for Trans-Pacific Partnership (2018), Article 29.5 in relation to tobacco control measures, which allows a Contracting State to deny benefits with respect to such claims and specifying that "[s]uch a claim shall not be submitted to arbitration under Section B of Chapter 9 (Investment) if a Party has made such an election". This provision is however without prejudice to "a Party's rights under Chapter 28 (Dispute Settlement) in relation to a tobacco control measure" (see footnote 11) (i.e. SSDS). The United States-Mexico-Canada Agreement (USMCA), Chapter 14 Appendix 2, carves out from the jurisdiction of investorState tribunals disputes arising from State measures taken to reduce tobacco consumption or debt restructuring.
} 
Kaufmann-Kohler G (2004) Annulment of ICSID awards in contract and treaty arbitrations: are there differences? In: Gaillard E, Banifatemi Y (eds) Annulment of ICSID awards: the foundation of a new investment protection regime in treaty arbitration. IAI Series, No. 1. JurisNet, pp 189-221

Kaufmann-Kohler G (2005) In search of transparency and consistency: ICSID reform proposal. Transnl Disp Manag 2(5):8

Kaufmann-Kohler G (2007) Arbitral precedent: dream, necessity or excuse? The 2006 Freshfields lecture. Arbitr Int 23(3):357-378

Kaufmann-Kohler G, Rigozzi A (2015) International arbitration law and practice in Switzerland. Oxford University Press, p 528

Marotti L (2017) Determining the scope of the local remedies rule in UNCLOS disputes. In: Lachenmann F, Wolfrum R (eds) Max Planck Yearbook of United Nations law, vol 21. Brill I Nijhoff, pp 36-62

Mbengue MM, Schacherer S (2017) The 'Africanization' of international investment law: the Pan-African investment code and the reform of the international investment regime. J World Invest Trade 18(3):414-448

McGarry B, Ostřanský J (2017) Is the law of treaties an obstacle or a conduit for the reform of investor-state dispute settlement? Emory Int Law Rev 32:1001-1013

Potestà M (2012) Republic of Italy v. Republic of Cuba. Am J Int Law 106:341-347

Potestà M (2015) Towards a greater role for state-to-state arbitration in the architecture of investment treaties? In: Lalani S, Polanco R (eds) The role of the state in investor-state arbitration. Brill I Nijhoff, pp 249-273

Roberts A (2018) Incremental, systemic, and paradigmatic reform of investor-state arbitration. Am J Int law 112(3):410-432

Schill SW, Vidigal G (2018) Cutting the Gordian Knot: Investment Dispute Settlement à la Carte. RTA Exchange, Geneva International Centre for Trade and Sustainable Development and the Inter-America Development Bank, p 19

Schreuer CH (2006) Diversity and harmonization of treaty interpretation in investment arbitration. Transnl Disp Manag 3(2):23

Schreuer CH (2008) Preliminary rulings in investment arbitration. In: Sauvant K (ed) Appeals mechanism in international investment disputes. Oxford University Press, pp 207-212

Shany Y (2007) Regulating jurisdictional relations between National and International Courts. Oxford University Press, pp 27-77

Stigen J (2008) The relationship between the International Criminal Court and National Jurisdictions: the principle of complementarity. Brill I Nijhoff

van den Berg AJ (2019) Appeal mechanisms for ISDS awards: interaction with New York and ICSID Conventions. In: Asian Academy of International Law's proceedings ISDS reform conference 2019, mapping the way forward, Hong Kong SAR, China, (13 February 2019), pp 104-107

Vidigal G, Stevens B (2018) Brazil's new model of dispute settlement for investment: return to the past or alternative for the future? J World Invest Trade 19:475-512

Virzo R (2011) The preliminary ruling procedures at international regional courts and tribunals. Law Prac Int Courts Tribunals 10(2):285-313 
Open Access This chapter is licensed under the terms of the Creative Commons Attribution 4.0 International License (http://creativecommons.org/licenses/by/4.0/), which permits use, sharing, adaptation, distribution and reproduction in any medium or format, as long as you give appropriate credit to the original author(s) and the source, provide a link to the Creative Commons licence and indicate if changes were made.

The images or other third party material in this chapter are included in the chapter's Creative Commons licence, unless indicated otherwise in a credit line to the material. If material is not included in the chapter's Creative Commons licence and your intended use is not permitted by statutory regulation or exceeds the permitted use, you will need to obtain permission directly from the copyright holder. 